\title{
PENGARUH PEMBANGUNAN INFRASTRUKTUR TERHADAP PERTUMBUHAN EKONOMI PROVINSI JAMBI (Pendekatan Fungsi Cobb Douglas)
}

\author{
Oleh: \\ *) Yunie Rahayu, S.E., M.E. \\ *) Ahmad Soleh, S.E., M.E. \\ *) Dosen Tetap STIE Muhammadiyah Jambi
}

\begin{abstract}
Abstrak
Infrastruktur merupakan modal utama yang harus dimiliki negara. Pembangunan infrastruktur mutlak diperlukan terutama dalam upaya meningkatkan perekonomian suatu daerah. Dengan adanya infrastruktur dapat mempermudah aktifitas ekonomi masyarakat dan juga meningkatkan produktifitas serta output/pendapatan. Infrastruktur ekonomi merupakan aset fisik yang menyediakan jasa dan digunakan dalam produksi dan konsumsi final yang meliputi public utilities (telekomunikasi, air minum, sanitasi dan gas), public works (jalan, bendungan dan saluran irigasi dan drainase) serta sektor transportasi (jalan kereta api, angkutan pelabuhan dan lapangan terbang).

Pembangunan infrastruktur memiliki karakteristik monopoli alamiah, dimana skala ekonomis yang diperlukan untuk menyediakan infrastruktur tersebut sedemikian besar sehingga diperlukan keterlibatan pemerintah dalam mengalokasikan sumber daya dalam pengelolaannya, baik secara langsung maupun dengan bekerjasama dengan pihak swasta. Keberadaan infrastruktur secara umum dapat memberikan pengaruh positif dan signifikan terhadap produktifitas dan pertumbuhan ekonomi.

Tujuan utama dari penelitian ini adalah ingin melihat signifikansi pengaruh pembangunan infrastruktur terhadap pertumbuhan ekonomi di Provinsi Jambi. Penelitian ini dilakukan di 11 kabupaten/kota di Provinsi Jambi. Metode yang digunakan dalam penelitian ini adalah deskriptif kualitatif dan kuantitatif, dengan menggunakan data sekunder yang bersumber dari Badan Pusat Statistik (BPS) dan dinas Pekerjaan Umum (PU) pemerintah Provinsi Jambi dan literatur-literatur yang diperlukan. Selanjutnya model analisis yang digunakan adalah analisis ekonometrik data panel, dengan variabel infrastruktur yang digunakan adalah infrastruktur dasar yaitu Pendidikan, jalan, listrik dan telepon.

Hasil penelitian diperoleh bahwa infrastruktur jalan, listrik, dan telepon berpengaruh positif terhadap output yang dihasilkan, sementara pendidikan justru berpengaruh negative terhadap pertumbuhan ekonomi.
\end{abstract}

Kata kunci: Infrastruktur, Pertumbuhan Ekonomi.

\section{Pendahuluan}

Tujuan utama dalam pembangunan adalah meningkatkan kesejahteraan masyarakat. Pertumbuhan ekonomi merupakan salah satu indikator untuk melihat hasil pembangunan yang telah dilakukan dan juga berguna untuk menentukan arah pembangunan di masa yang akan datang. 
Pertumbuhan ekonomi dipengaruhi oleh akumulasi modal berupa investasi pada tanah, peralatan dan mesin, sarana, sumber daya alam, sumber daya manusia (human resources) secara kualitas dan kuantitas, juga oleh kemajuan teknologi, akses informasi, inovasi dan kemampuan pengembangan diri serta budaya kerja (Todaro,2000). Investasi produktif yang bersifat langsung harus dilengkapi dengan investasi penunjang yang disebut dengan investasi infrastruktur, yang semuanya mutlak dibutuhkan dalam menunjang dan mengintegrasikan segenap aktifitas ekonomi produktif. Umumnya para ekonom sepakat bahwa pembangunan infrastruktur dapat mempercepat laju pertumbuhan ekonomi. Keberadaan infrastruktur dapat meningkatkan produktifitas dan hasil (output) bagi penduduk, dimana infrastruktur dapat mempermudah dan meningkatkan intensitas kegiatan ekonomi.

Peran infrastruktur cukup signifikan dalam mengakselerasi pembangunan ekonomi secara umum. Beberapa terminologi infrastruktur menjangkau hal yang lebih luas, misalnya The World Bank (1994) memberikan batasan infrastruktur terbagi atas infrastruktur ekonomi berupa public utilities (tenaga listrik, telekomunikasi, air, sanitasi, gas), public work (jalan, bendungan, jembatan, kanal, irigasi dan drainase), dan sektor transportasi (rel kerta api, terminal bus, pelabuhan dan bandar udara), infrastruktur sosial seperti pendidikan, kesehatan, perumahan dan rekreasi serta infrastruktur administrasi berupa penegakan hukum, kontrol administrasi dan koordinasi.

Peningkatan investasi dalam infrastruktur, akan memberikan dampak bagi perekonomian yang tidak hanya terasa secara langsung, seperti pembukaan lapangan kerja, tetapi juga secara tidak langsung. Infrastruktur adalah prasyarat bagi sektor-sektor lain untuk berkembang dan juga sebagai sarana penciptaan hubungan antara yang satu dengan lainnya. Lebih jauh lagi, dengan pemberdayaan sumber daya untuk membangun infrastruktur, kita akan dapat memicu lingkaran proses ekonomi sehingga akan timbul penggandaan dampak ekonomi maupun sosial.

Pembangunan Infrastruktur terutama yang bersifat dasar seperti, prasarana transportasi (jalan, rel kereta api, pelabuhan laut, pelabuhan udara) dan jaringan listrik sangatlah penting dalam rangka meningkatkan perekonomian masyarakat suatu daerah. Daerah dengan prasarana yang mencukupi mempunyai keuntungan yang lebih besar dalam usaha, serta menarik investasi untuk masuk ke daerahnya sehingga perkembangan daerah tersebut akan lebih cepat bila dibandingkan dengan daerah yang minim prasarananya.

Kondisi infrastruktur di Propinsi Jambi saat ini bila dibandingkan dengan beberapa propinsi lain di Sumatera adalah sebagai berikut: 
1. Rumah tangga di Propinsi Jambi yang belum memperoleh aliran listrik sebesar 17,35 persen sementara di Propinsi lainnya di Sumatera (Aceh, Sumut, Sumbar, Riau, Kepri, Babel) antara 7-15 persen kecuali Bengkulu, Sumsel dan Lampung.

2. Dari total panjang jalan di Propinsi Jambi, 50,93\% diantaranya dalam kondisi rusak (tahun 2000), sedangkan pada tahun 2009 masih 42,26 \% dari total panjang jalan dalam kondisi rusak.

Rendahnya penyediaan infrastruktur tersebut antara lain disebabkan oleh (i) rendahnya kualitas pelayanan, (ii) cakupan yang terbatas, (iii) pelayanan tidak berkelanjutan, (iv) kurangnya keterbukaan dan fairness dalam kebijakan tarif, (v) kerancuan dan ketidakpastian kerangka pengaturan, (vi) ketidakpastian pembebasan lahan, (vii) kemampuan pendanaan yang terbatas (KKPPI,2005).

Rendahnya penyediaan infrastruktur tersebut ditambah lagi dengan buruknya kondisi infrastruktur yang ada, diantaranya disebabkan oleh menurunnya investasi infrastruktur secara perlahan sejak krisis tahun 1997. Akibatnya jalan semakin rusak, pasokan tenaga listrik semakin tidak memadai dan lain sebagainya. Bahkan banyak jalan kabupaten yang tidak pernah berada dalam kondisi baik dan mantap, rata-rata setengahnya berada dalam kondisi rusak baik ringan maupun sedang.

Didasarkan bahwa investasi disektor infrastruktur telah berlangsung cukup lama dengan biaya yang sangat besar, pengaruhnya dalam peningkatan pertumbuhan ekonomi cukup signifikan, namun juga menyebabkan ketimpangan output sebagai akibat kebijakan pembangunan yang lebih berorientasi pertumbuhan daripada pemerataan. Maka penulis tertarik untuk melakukan penelitian ini dengan judul "Pengaruh Pembangunan Infrastruktur Terhadap Pertumbuhan Ekonomi Propinsi Jambi (Pendekatan Fungsi Cobb-Douglas)".

Dengan tujuan penelitian meliputi: (1) Untuk mengetahui pengaruh infrastruktur jalan, listrik, dan telpon terhadap Pertumbuhan Ekonomi propinsi Jambi; (2) Untuk mengetahui besarnya pengaruh masing-masing infrastruktur jalan, listrik, dan telepon terhadap pertumbuhan ekonomi Propinsi Jambi.

\section{Metode Penelitian}

Metode penelitian yang digunakan dalam penelitian ini adalah metode Deskriptif dan metode Kuantitatif dengan menggunakan data sekunder dan tehnik penugmpulan pooling data yang dilaksanakan di lingkungan pemerintah Kabupaten/kota di Provinsi Jambi. 


\section{Metode Analisis Data}

Dalam penelitian ini analisis data yang digunakan adalah analisis kuantitatif dengan metode analisis ekonometrika disertai analisis deskriptif yang menjelaskan dan mendukung metode analisis ekonometrika.

\section{Analisis Deskriptif}

Analisis deskriptif digunakan untuk memberikan gambaran umum kondisi perekonomian di propinsi Jambi, khususnya data tentang perkembangan PDRB perkapita propinsi Jambi dan perkembangan ketersediaan infrastruktur. Analisis ini dilakukan melalui tabel dan grafik yang berisi hasil olahan data, sehingga diperoleh peubah-peubah yang diperlukan untuk analisis selanjutnya.

\section{Analisis Kuantitatif}

Dari perumusan masalah yang dibangun serta hipotesis yang ditetapkan, maka untuk menguji kebenaran hipotesis pertama dan hipotesis kedua, pendekatan model yang digunakan untuk mengestimasi persamaan pengaruh infrastruktur terhadap pertumbuhan ekonomi Propinsi Jambi adalah pengembangan dari fungsi Cobb-Douglas:

$$
\mathrm{Y}_{\mathrm{lt}}=\mathrm{A}_{\mathrm{lt}} \mathrm{K}_{\mathrm{lt}}^{\alpha} \mathrm{L}_{\mathrm{lt}}^{1-\alpha} \mathrm{U}_{\mathrm{lt}}
$$

Untuk penelitian ini, dimana modal infrastruktur (dan juga modal manusia) merupakan input terhadap produksi agregat. Karena keterbatasan data maka model ekonometrika yang digunakan mempunyai bentuk yang tidak sama persis dengan model yang digunakan Canning dalam mengestimasi persamaan model The Contribution of Infrastructures to Agregate Output, sehingga model yang digunakan yaitu :

$$
\mathrm{Y}_{\mathrm{lt}}=\mathrm{A}_{\mathrm{lt}} \mathrm{H}_{\mathrm{lt}}^{\alpha} \mathrm{X}_{\mathrm{lt}}^{\beta} \mathrm{L}_{\mathrm{lt}}^{1-\alpha-\beta} \mathrm{U}_{\mathrm{lt}}
$$

Dimana Y adalah Produk Domestik Regional Bruto (Output), A adalah Total Faktor Produksi (Total Factor Productivity), H adalah Modal Manusia (Human Capital), X adalah modal infrastruktur (infrastructure capital), L adalah jumlah penduduk (Population), U adalah galat, i adalah indeks kabupaten/kota dan t adalah indeks waktu.

Diasumsikan constant return to scale sehingga penjumlahan eksponen adalah satu. Asumsi yang digunakan pada model tersebut adalah total faktor produksi mempunyai bentuk $\log A_{l t}=a_{1}+b_{t}$ yang merupakan fixed effect dari masing-masing kabupaten/kota dengan indeks i dan indeks t sebagai produktifitas dalam waktu tertentu.

Dari persamaan tersebut diatas, masing-masing variabel dibagi dengan jumlah penduduk dan di log kan sehingga menjadi :

$$
(\mathrm{Y} / \mathrm{L})_{\mathrm{lt}}=(\mathrm{A} / \mathrm{L})_{\mathrm{lt}}(\mathrm{H} / \mathrm{L})_{\mathrm{lt}}^{\alpha}(\mathrm{X} / \mathrm{L})_{\mathrm{lt}}^{\beta}(\mathrm{L} / \mathrm{L})_{\mathrm{lt}}^{1-\alpha-\beta} \mathrm{U}_{\mathrm{lt}}
$$




$$
\begin{aligned}
& \log (\mathrm{Y} / \mathrm{L})_{\mathrm{lt}}=\log (\mathrm{A} / \mathrm{L})_{\mathrm{lt}}+\alpha \log (\mathrm{H} / \mathrm{L})_{\mathrm{lt}}+\beta \log (\mathrm{X} / \mathrm{L})_{\mathrm{lt}}+\log \mathrm{U}_{\mathrm{lt}} \\
& \mathrm{y}_{\mathrm{lt}}=\mathrm{a}_{\mathrm{l}}+\mathrm{b}_{\mathrm{t}}+\alpha \mathrm{h}_{\mathrm{lt}}+\beta \mathrm{x}_{\mathrm{lt}}+\mathrm{u}_{\mathrm{lt}}
\end{aligned}
$$

Dimana stok modal dan output berada dalam bentuk log per jumlah penduduk dan $\mathrm{u}_{\mathrm{lt}}=\log \mathrm{U}_{\mathrm{lt}}$ Pada penelitian ini, modal infrastruktur kemudian dipecah menjadi 3 variabel infrastruktur yaitu panjang jalan $(\mathrm{km})$, kapasitas listrik (kwh), dan jumlah sambungan telpon (sst). Kemudian faktor dummy otonomi daerah dimasukkan dalam persamaan. Oleh sebab itu model persamaan dapat menjadi :

$$
\mathrm{y}_{l t}=\mathrm{a}_{1}+\mathrm{b}_{\mathrm{t}}+\alpha \mathrm{h}_{\mathrm{lt}}+\beta_{1 \mathrm{j}} \mathrm{l}_{\mathrm{lt}}+\beta_{2} \mathrm{lis}_{\mathrm{lt}}+\beta_{3} \mathrm{tel}_{\mathrm{l}}+\mathrm{u}_{\mathrm{lt}}
$$

dimana :

y : PDRB perkapita dari setiap kab/kota dari tahun 2005 sampai dengan 2014, dengan menggunakan tahun dasar 2000 .

j1 : Merupakan panjang jalan $(\mathrm{km})$ perkapita yang tersedia di setiap kab/kota dari tahun 2005 sampai dengan 2014. Panjang jalan yang digunakan adalah semua jalan yang termasuk dalam golongan jalan negara, jalan propinsi dan jalan kabupaten/kota tanpa memperdulikan kondisi jalan tersebut.

lis : Produksi listrik perkapita (kwh) yang dijual Perusahaan Listrik Negara di setiap kab/kota yang digunakan oleh semua pengguna listrik dari segala golongan dari tahun 2005 sampai dengan tahun 2014.

tel : Jumlah sambungan telepon (sst) perkapita yang meliputi seluruh sambungan telepon induk terpasang di setiap kab/kota dari tahun 2005 sampai dengan tahun 2014.

h $\quad$ : Modal manusia perkapita yang merupakan indeks pendidikan penduduk.

Pada pendekatan model ini diasumsikan bahwa ada tingkat optimal dari infrastruktur yang akan memaksimalkan tingkat pertumbuhan, jika infrastruktur berada dibawah tingkat optimalnya maka penambahan stok infrastruktur akan cenderung meningkatkan output sementara jika berada diatas tingkat optimalnya, penambahan stok infrastruktur akan mengurangi outputnya (Canning \& Pedroni, 1992).

Dalam pendekatan yang digunakan untuk mengestimasi hubungan antara stok infrastruktur dan output maka untuk pengukuran kapasitas infrastruktur digunakan ukuran fisik infrastruktur tersebut seperti panjang jalan (km), kapasitas listrik (kwh), dan jumlah telepon (sst). Penggunaan ukuran fisik ini kemungkinan lebih baik jika dibandingkan dengan penggunaan besaran investasi (Canning \& Pedroni, 1999).

Dalam melakukan perumusan model ada beberapa pertimbangan yang harus dipertimbangkan, diantaranya adalah : 
a) Model yang digunakan hanya memasukkan variabel-variabel yang dianggap penting saja dan dipilih berdasarkan kepada teori ekonomi serta fenomena yang sesuai. Secara konseptual memang merupakan penyederhanaan fakta sehingga suatu model tidak untuk menjelaskan semua fenomena yang ada dalam dunia nyata. Model dibangun agar dapat dipakai sebagai panduan bagi peneliti dalam mengestimasi atau memprediksi parameter atau perilaku ekonomi yang sedang diamati.

b) Model yang digunakan dikatakan baik jika model tersebut mempunyai adminisibilitas dengan data dalam arti bahwa model tersebut tidak mempunyai kemampuan untuk memprediksi besaran-besaran ekonomi yang menyimpang dari definisi ekonomika.

c) Model yang digunakan juga harus koheren dengan data dalam pengertian bahwa model tersebut harus mampu menjelaskan data yang ada. Biasanya kriteria ini dikaji melalui uji keserasian atau goodness of fit $\left(\mathrm{R}^{2}\right)$.

d) Parameter yang diestimasi harus konstan dalam arti bahwa parameter dari model tersebut adalah besaran statistik yang deterministik dan bukan stokastik.

e) Model yang digunakan tersebut harus konsisten dengan teori ekonomi yang dipilih.

Yang selanjutnya diteruskan dengan melakukan Uji Kesesuaian (Uji R ${ }^{2}$, Uji F-Statistik, Uji t-statistik) dan Uji Penyimpangan Asumsi Klasik (heteroskedastisitas, autokorelasi dan multikolinearitas). Panel Data Model merupakan perluasan dari model regresi klasik sehingga penanganan terhadap ketiga masalah diatas sama seperti pada persamaan tunggal.

\section{Hasil Penelitian}

\section{Pengaruh Infrastruktur Terhadap Pertumbuhan Ekonomi Provinsi Jambi}

Berdasarkan hasil estimasi regresi pengaruh infrastruktur terhadap pertumbuhan ekonomi di Propinsi Jambi didapatkan hasil sebagai berikut :

Tabel.1. Perbandingan Hasil Estimasi Pengaruh Infrastruktur Terhadap Pertumbuhan Ekonomi/Output di Provinsi Jambi.

\begin{tabular}{|c|c|c|c|c|c|c|c|c|}
\hline \multirow{3}{*}{$\begin{array}{c}\text { Variabel } \\
\text { Independen }\end{array}$} & \multicolumn{8}{|c|}{ Variabel dependen : PDRB perkapita } \\
\hline & \multicolumn{2}{|c|}{ Prov.Jambi } & \multicolumn{2}{|c|}{ Wilayah Barat } & \multicolumn{2}{|c|}{ Wilayah Tengah } & \multicolumn{2}{|c|}{ Wilayah Timur } \\
\hline & Coef & Prob & Coef & Prob & Coef & Prob & Coef & Prob \\
\hline Pendidikan & $-2,934$ & 0,0000 & $-3,338$ & 0,0000 & $-1,731$ & 0,0000 & $-9,537$ & 0,0001 \\
\hline Jalan & 0,499 & 0,0000 & $-0,151$ & 0,6324 & 1,828 & 0,0000 & 0,760 & 0,0466 \\
\hline Listrik & 0,591 & 0,0000 & 0,621 & 0,0000 & 1,049 & 0,0000 & $-0,083$ & 0,6685 \\
\hline Telepon & 0.067 & 0,0000 & 0,096 & 0,0056 & 0,095 & 0.0900 & $-0,224$ & 0,5591 \\
\hline Adjust R-Sqr & \multicolumn{2}{|l|}{0,97} & \multicolumn{2}{|l|}{0,93} & \multicolumn{2}{|l|}{0,96} & \multicolumn{2}{|l|}{0,95} \\
\hline Durbin-Watson & \multicolumn{2}{|l|}{1,73} & \multicolumn{2}{|l|}{1,60} & \multicolumn{2}{|l|}{1,08} & \multicolumn{2}{|l|}{1,10} \\
\hline
\end{tabular}

Sumber : Disarikan dari lampiran. 
Berdasarkan tabel diatas, dari masing-masing variabel bebas, ternyata infrastruktur listrik mempunyai nilai elastisitas yang terbesar yaitu sebesar 0,591 disusul oleh jalan sebesar 0,499 lalu telepon sebesar 0,067 dan terakhir pendidikan mempunyai elastisitas negatif yaitu sebesar 2,934 .

Jika dilihat lebih jauh, dari hasil uji t semua variabel bebas memperlihatkan signifikansi yang tinggi yang ditunjukkan dengan nilai t-statistik (t-hitung) yang lebih besar dari nilai $t$ tabel atau nilai probabilitas $(\mathrm{p}=0,0000)$ yang lebih kecil dari pada 0,01 (signifikan pada alpha/ $\alpha$ $=1 \%$ ). Ini berarti bahwa masing-masing variabel bebas secara sendiri-sendiri berpengaruh terhadap variabel terikat. Demikian juga dari hasil uji $\mathrm{F}$ terlihat bahwa secara bersama-sama variabel bebas mempengaruhi variabel terikat yang ditunjukkan dengan nilai F-statistik cukup besar $(\mathrm{F}$-statistik $=254,7279)$ atau probabilitas (prob F-stat $=0,0000)$ yang lebih kecil dari pada 0,01 (signifikan pada alpha/ $\alpha=1 \%$ ).

Selanjutnya jika hasil estimasi pada tabel diatas dimasukkan kedalam persamaan regresinya maka akan diperoleh persamaan sebagai berikut ;
$\log ($ PDRB
$\mathrm{t} \quad(-14,01078)$
$(0,0000)$
$(7,086751)$
$(21,65580)$
$(0,0000)$
$(0,0000)$

Pada penelitian yang dilakukan oleh Canning tentang kontribusi infrastruktur terhadap output ( The Contribution of Infrastructure to Agregate Output) faktor Investasi non Infrastruktur mempunyai elastisitas terbesar yaitu 0,371 , kemudian diikuti oleh infrastruktur telepon dengan elastisitas sebesar 0,144. Faktor modal manusia (pendidikan) dengan elastisitas sebesar 0,087 merupakan yang terbesar ketiga kemudian diikuti oleh infrastruktur listrik sebesar 0,035, sedangkan infrastruktur jalan memberikan kontribusi negatif terhadap output yaitu sebesar -0,028. Adanya perbedaan pada penelitian ini dengan penelitian yang dilakukan oleh Canning disebabkan oleh perbedaan lokasi penelitian, kondisi demografis dan perbedaan penggunaan satuan variabel. Demikian juga dengan penelitian Sibarani terhadap 26 provinsi di Indonesia (2002), Setiadi terhadap 8 provinsi di Sumatera dan Amrullah terhadap 33 provinsi di Indonesia (2006), terdapat perbedaan dengan hasil penelitian ini. Kenyataan ini disebabkan oleh cakupan wilayah penelitian dan adanya perbedaan waktu serta penggunaan variabel yang tidak sama, misalnya dengan adanya variabel infrastruktur air bersih dan penggunaan variabel dummy otonomi daerah dan sebagainya.

Hasil penelitian Amrullah menyebutkan bahwa faktor infrastruktur telepon memberikan kontribusi terbesar dengan elastisitas terhadap output sebesar 0,132, kemudian infrastruktur listrik sebesar 0,130 dan diikuti oleh investasi non infrastruktur dan infrastruktur jalan masing- 
masing sebesar 0,113 dan 0,090 dan selanjutnya adalah modal manusia (factor pendidikan) sebesar 0,034 dan terakhir air bersih dengan elastisitas sebesar 0,013. Selengkapnya, beberapa hasil penelitian terdahulu mengenai kontribusi infrastruktur terhadap pertumbuhan output (PDRB/kapita) dapat dilihat pada tabel dibawah ini.

Tabel 2. Perbandingan Hasil Penelitian Pengaruh Infrastruktur Terhadap Pertumbuhan Output

\begin{tabular}{|l|r|r|r|r|}
\hline \multicolumn{1}{|c|}{ Variabel Independen } & \multicolumn{1}{c|}{$\begin{array}{c}\text { Canning } \\
\text { Wilayah dan Tahun }\end{array}$} & $\begin{array}{c}\text { Sibarani } \\
(2002)\end{array}$ & $\begin{array}{c}\text { Setiadi } \\
(2006)\end{array}$ & $\begin{array}{c}\text { Amrullah } \\
(2006)\end{array}$ \\
\hline Telepon & $1960-1990$ & $\begin{array}{c}\text { Indonesia } \\
\text { I983-1997 }\end{array}$ & $\begin{array}{c}\text { 8 Propinsi di } \\
\text { Sumatera } \\
1983-2003\end{array}$ & $\begin{array}{c}\text { 26 Propinsi } \\
\text { di Indonesia } \\
1994-2002\end{array}$ \\
\hline Listrik & 0,144 & 0,007 & 0,100 & 0,132 \\
\hline Jalan & 0,035 & 0,057 & 0,067 & 0,130 \\
\hline Air Bersih & $-0,028$ & 0,013 & $-0,013$ & 0,090 \\
\hline Modal Manusia/Penddkn & - & - & - & 0,013 \\
\hline $\begin{array}{l}\text { Modal / Investasi (non } \\
\text { infrastruktur) }\end{array}$ & 0.371 & $-0,067$ & 0,087 & 0,034 \\
\hline Dummy Krisis & - & -0.013 & 0,067 & 0,113 \\
\hline Dummy Otda & - & - & - & -0.078 \\
\hline
\end{tabular}

Sumber: Hasil Penelitian terkait.

\section{Pengaruh Pendidikan Terhadap Pertumbuhan Ekonomi Provinsi Jambi}

Variabel diluar variabel infrastruktur yang digunakan dalam model pada penelitian ini adalah pendidikan yang besar elastisitasnya adalah -2,934. Variabel pendidikan memiliki pengaruh yang signifikan terhadap pertumbuhan ekonomi yang ditunjukkan dengan nilai probabilitas $(\mathrm{p}=0,0000)$ yang lebih kecil dari pada 0,01 (signifikan pada alpha/ $\alpha=1 \%$ ), namun arahnya tidak sama dengan teori yang ada (negatif). Hasil ini berbeda dengan hasil penelitianpenelitian sebelumnya. Ini menunjukkan bahwa bahwa tingkat atau kualitas pendidikan penduduk di Provinsi Jambi masih rendah.

Walaupun pemerintah telah mencanangkan wajib belajar 9 tahun semenjak tahun 1994 guna meningkatkan kualitas sumber daya manusia, namun kebijakan ini belum memberikan hasil yang diinginkan. Pada tahun 2009 (Susenas 2009) hanya 5,36\% (D1\&D2=1,18\%; D3\% Sarmud $=1,23 \% ; \mathrm{D} 4 \% \mathrm{~S} 1=2,79 \%$; S2\&S3=0.16\%) penduduk usia 10 tahun keatas yang tamat Perguruan Tinggi; 24,87\% tidak tamat SD ; lulus SD/MI 30,22\%; lulus SLTP/sederajat 19,84\%; lulus SLTA/sederajat 19,71\%. Terlihat bahwa program wajib belajar masih belum sesuai dengan hara-pan karena masih lebih dari $55 \%$ penduduk yang belum lulus SLTP/ sederajat. Tanpa adanya kebijakan baru yang lebih progresif (misalnya dengan membuat anggaran untuk pendidikan yang lebih besar) maka program tersebut akan sukar diwujudkan dalam waktu lebih cepat. 
Disamping itu rendahnya tingkat pendidikan juga disebabkan oleh rendahnya daya tampung sekolah sebagai akibat dari prasarana yang tidak mencukupi. Selain itu masih adanya sebagian masyarakat terutama di daerah pedesaan yang tidak mau lagi melanjutkan sekolah anak-anaknya setelah lulus sekolah dasar dengan alasan membantu orang tua dan lain sebagainya. Selain itu penduduk yang tamat Perguruan Tinggi, latar belakang bidang pendidikan yang dimiliki ditenggarai tidak sesuai dengan bidang pekerjaan yang dilakukannya maupun kesempatan/ lowongan yang tersedia.

\section{Pengaruh Infrastruktur Jalan Terhadap Pertumbuhan Ekonomi Provinsi Jambi}

Jalan memiliki elastisitas positif sebesar 0,499 yang berarti bahwa setiap terjadi penambahan panjang jalan sebesar $1 \%$ maka akan meningkatkan output sebesar 0,499\% dengan asumsi ceteris paribus. Variabel infrastruktur Jalan memiliki pengaruh yang signifikan terhadap pertumbuhan ekonomi yang ditunjukkan dengan nilai probabilitas $(p=0,0000)$ yang lebih kecil dari pada 0,01 (signifikan pada alpha/ $\alpha=1 \%$ ) dan nilai t-hitung $(7,086451)$ lebih besar dari nilai t-tabel.

Hal ini sesuai dengan teori yang ada yang menyatakan bahwa semakin meningkatnya kapital/modal dalam hal ini dinyatakan oleh infrastruktur jalan maka output juga akan semakin meningkat. Peningkatan output ini akan berdampak terhadap peningkatan pertumbuhan ekonomi. Sebagai contoh adalah jika seorang petani ingin meningkatkan hasil produksi pertaniannya dengan membeli traktor baru tetapi didaerahnya tidak terdapat fasilitas jalan yang baik guna mengangkut tambahan produksi pertanian petani tersebut kepasar maka investasi dari petani tersebut tidak akan banyak menambah produksi pangan di wilayah tersebut.

Ketersediaan infrastruktur jalan di kabupaten/kota di provinsi Jambi memang sangat mempengaruhi aktifitas sehari-hari dari sebagian besar penduduk Jambi karena jalan memegang peranan penting dalam mobilitas masyarakat dan perekonomian yang ada. Agar kontribusi jalan terhadap peningkatan output dapat semakin meningkat maka pemerintah perlu menggiatkan pembangunan jalan terutama untuk daerah-daerah yang masih terisolir. Ketersediaan jaringan jalan di daerah-daerah yang masih terisolir merupakan prasyarat utama karena akan lebih memudah kan dalam penyediaan akses terhadap pendidikan, kesehatan, informasi dan pasar.

Sampai saat ini ketergantungan masyarakat Jambi terhadap moda jalan darat sangat besar jika dibandingkan dengan moda lainnya seperti angkutan sungai dan laut. Oleh karena itu penurunan kapasitas dan tingkat pelayanan jalan sangat mempengaruhi kelancaran pergerakan ekonomi masyarakat dan akan menyebabkan biaya sosial yang tinggi terhadap pengguna jalan tersebut. 
Penurunan kondisi jaringan jalan pada beberapa tahun terakhir ini terutama disebabkan oleh krisis yang terjadi sehingga pemerintah mengurangi anggaran untuk sarana transportasi dan bahkan member-hentikan beberapa pengembangan jaringan jalan serta berkurangnya anggaran untuk perawatan dan pemeliharaan jaringan jalan yang sudah ada. Selain itu kondisi jalan yang tidak memadai itu juga disebabkan oleh kualitas pengerjaan yang tidak optimal, pembebanan yang berlebih (excessive overloading) serta terjadinya berbagai bencana alam (banjir dan longsor).

\section{Pengaruh Infrastruktur Listrik Terhadap Pertumbuhan Ekonomi Provinsi Jambi}

Infrastruktur Listrik memiliki nilai elastisitas tertinggi yaitu sebesar 0,591 yang menunjukkan bahwa setiap kenaikan 1\% ketersedian energi listrik maka akan meningkat output sebesar $0,591 \%$. Hal ini sesuai dengan teori yang menyatakan bahwa semakin meningkatnya infrastruktur listrik yang merupakan modal fisik maka akan semakin meningkatkan output yang ada dan berarti akan berdampak terhadap peningkatan pertumbuhan ekonomi. Pada penelitian ini infrastruktur Listrik juga menunjukkan signifikansi yang tinggi yang ditunjukkan oleh nilai probabilitas $(\mathrm{p}=0,0000)$ yang lebih kecil dari pada 0,01 (signifikan pada alpha/ $\alpha=$ $1 \%)$ dan nilai t-hitung $(21,65580)$ lebih besar dari nilai t-tabel.

Listrik merupakan salah satu bentuk energi terpenting dalam perkembangan kehidupan manusia modern, baik untuk keperluan rumahtangga, pendidikan, kesehatan, usaha, industri maupun kegiatan lainnya mulai dari komunitas pengguna dikota besar sampai di pelosok pedesaan. Jika terjadi kekurangan pasokan tenaga listrik dapat menyebabkan pemadaman yang tentu akan sangat merugikan berbagai kegiatan ekonomi.

Ketersediaan listrik sangat dibutuhkan dalam berbagai kegiatan ekonomi terutama untuk sektor-sektor ekonomi seperti pertanian, industri yang harus menggunakan teknologi dan mesin yang memerlukan listrik untuk meningkatkan produksinya. Kesejahteraan masyarakat akan semakin meningkat dengan tersedianya listrik dalam kapasitas yang cukup karena masyarakat dapat menggunakan berbagai fasilitas-fasilitas yang akan membantu penyelesaian pekerjaannya. Sedangkan jika terjadi kekurangan listrik akan dapat meningkatkan biaya unit produksi kegiatan ekonomi yang akan mempengaruhi secara negatif keseluruhan kesempatan investasi dan juga mengurangi kesejahteraan masyarakat.

Pemerintah perlu lebih memperhatikan penyediaan listrik terutama untuk kondisi bahwa kapasitas yang ada sudah tidak mencukupi. Agar ketersediaan listrik tetap terjamin maka pemerintah perlu menempuh langkah-langkah yang cukup berani dengan mengundang investor swasta dalam penyediaan listrik seperti yang terdapat dalam UU No. 20 Tahun 2002 tentang Ketenagalistrikan walaupun hingga saat ini masih dalam perdebatan. 
Kapasitas produksi listrik (listrik terjual) meningkat terus sejak 1995 hingga sekarang dengan tingkat perubahan 164,1 persen, namun produksi listrik di provinsi Jambi belum merata. Meskipun kapasitas produksi terus meningkat, namun permintaan konsumen terhadap energi listrik jauh melampaui peningkatan kapasitas produksi listrik tersebut. Pada saat ini, kemampuan PT.PLN untuk menyediakan daya listrik terba-tas pada hampir diseluruh daerah. Pemakaian listrik pada saat beban puncak seringkali sudah melampaui perkiraan kemampuan PLN untuk menyediakan pasokan listrik bagi konsumen.

Kondisi tersebut diperparah dengan perawatan pembangkit listrik yang kurang memenuhi standar sehingga otomatis terjadi pemadaman pada sebagian pelanggan. Pemadaman ini menunjukkan krisis liistrik dimana permintaan tidak seimbang dengan pasokan listrik.

\section{Pengaruh Infrastruktur Telepon Terhadap Pertumbuhan Ekonomi Provinsi Jambi}

Dari keempat infrastruktur yang digunakan dalam model ini, infrastruktur telepon memberikan nilai elastisitas yang paling rendah yaitu sebesar 0,067. Ini menunjukkan bahwa setiap kenaikan 1\% sambungan telepon menghasilkan peningkatan output sebesar 0,067\% dengan asumsi ceteris paribus. Sama dengan infrastruktur lainnya, infrastruktur telepon juga memiliki signifikansi yang tinggi yang ditunjukkan nilai t-hitung $(7,285169)$ yang lebih besar dari t-tabel atau nilai probabilitas $(\mathrm{p}=0,0000)$ yang lebih kecil dari pada 0,01 (signifikan pada alpha/ $\alpha=1 \%$ ). Hasil ini juga sesuai dengan teori bahwa dengan semakin meningkatnya modal fisik dalam hal ini jumlah sambungan telepon maka akan meningkatkan output yang ada yang berdampak terhadap pertumbuhan ekonomi. Dengan semakin meningkatnya ketersediaan jaringan telepon akan memudahkan masyarakat dalam melakukan kegiatan dan menghemat waktu dan tenaga untuk mengerjakan kegiatan lainnnya.

Kontribusi telepon terhadap peningkatan output dapat lebih ditingkatkan dengan meningkatkan pelayanan telepon. Oleh karena itu pemerintah ataupun pihak swasta masih perlu menginvestasikan dana yang cukup besar untuk mendorong peningkatan pelayanan telepon yang pada akhirnya dapat meningkatkan output.

\section{Implikasi Kebijakan}

Dari hasil penelitian ini dan beberapa hasil penelitian terkait yang pernah dilakukan, dapat ditarik benang merah bahwa infrastruktur penting bagi stabilitas pertumbuhan ekonomi dan terkendalinya laju inflasi. Ketersediaan infrastruktur yang semakin baik di suatu daerah, akan mempengaruhi tingkat penurunan inflasi daerah yang bersangkutan. 
Dengan mengetahui nilai elastisitas dari masing-masing infrastruktur, maka dapat diketahui jenis infrastruktur manakah yang memberikan pengaruh besar terhadap pertumbuhan ekonomi propinsi Jambi, sehingga dapat ditentukan arah kebijakan pemerintah dalam mengembangkan infrastruktur yang cocok dan memberikan nilai tambah yang signifikan bagi perkembangan suatu wilayah. Nilai elastisitas yang tinggi menunjukkan produktifitas yang lebih tinggi dari suatu infrastruktur dan juga memperlihatkan jenis infrastruktur ini masih under supply. Investasi pada infrastrutktur yang mempunyai nilai elastisitas tinggi akan lebih cepat meningkatkan pertumbuhan ekonomi (PDRB/kap). Hal ini didasarkan dengan asumsi bahwa biaya relatif dari setiap infrastruktur sama disetiap kabupaten/kota.

Dari penelitian ini dan dengan mempertimbangkan prioritas pembangunan maka pemerintah propinsi Jambi perlu mengembangkan infrastruktur listrik (dengan peningkatan kapasitas produksi energi listrik dan jangkauan layanan yang dapat menjangkau keseluruh daerah terutama daerah yang selama ini belum teraliri listrik) terlebih dahulu, Untuk bisa mencapai ini perlu dilakukan pengembangan dan pencarian sumber-sumber energi listrik yang baru (terutama sumber-sumber energi yang tidak menimbulkan kerusakan lingkungan ataupun sumber energi yang dapat terbarukan) disamping terus meningkatkan efisiensi pada pembangkit-pembangkit yang telah ada. Untuk pengembangan dan pembangunan infrastruktur listrik dibutuhkan investasi yang sangat besar, untuk itu pemerintah dapat bekerjasama dengan pihak swasta dalam pelaksanaannya.

Selanjutnya infrastruktur yang perlu dikembangkan lagi oleh pemerintah propinsi Jambi adalah infrastruktur jalan. Dari hasil penelitian infrastruktur jalan memberikan pengaruh terbesar kedua setelah listrik. Pemerintah propinsi Jambi perlu meningkatkan kapasitas jalan yang ada dengan membangun jalan-jalan baru terutama jalan yang menghubung kan daerahdaerah yang selama ini masih sulit dijangkau dengan jalan darat/daerah terisolir dan juga jalan yang dapat menjadi jalur jalan lintas/penghubung antar daerah atau antar wilayah disamping juga perlu melakukan peningkatan kualitas dan pemeliharaan jalan-jalan yang telah ada.

Selanjutnya infrastruktur yang perlu pengembangan dipropinsi Jambi adalah infrastruktur Air Bersih kemudian diikuti oleh infrastruktur Telepon. Dalam pembangunan maupun pengembangan infrastruktur dimaksud, hendaknya pemerintah propinsi Jambi juga harus memper hatikan aspek kewilayahan demi pemerataan pembangunan yang disesuaikan dengan prioritas yang ada dan infrastruktur mana yang memberikan pengaruh yang besar terhadap pertumbuhan ekonomi setiap wilayah.

Pelaksanaan otonomi daerah diharapkan dapat memberikan arah yang lebih positif bagi pembangunan infrastruktur secara merata di seluruh daerah di propinsi Jambi. Untuk itu 
pemerintah propinsi Jambi harus menjalin sinergitas yang lebih baik dengan pemerintah daerah kabupaten/kota dan menyiapkan konsepsi dan peraturan terkait pem bangunan infrastruktur.

\section{Kesimpulan Dan Saran}

\section{Kesimpulan}

Dari hasil penelitian mengenai pengaruh pembangunan infrastruktur terhadap pertumbuhan ekonomi di provinsi Jambi dapat ditarik kesimpulan sebagai berikut:

1. Dari hasil estimasi terhadap model persamaan diatas didapatkan bahwa infrastruktur jalan, listrik, dan telepon berpengaruh positif terhadap output yang dihasilkan. Pada penelitian ini output dimaksud adalah PDRB perkapita dimana PDRB perkapita merupakan ukuran pertumbuhan ekonomi yang terjadi dalam suatu daerah.

2. a. Pada penelitian ini pendidikan memberikan pengaruh yang negatif yaitu sebesar -2,934. Kenyataan ini juga didukung oleh masih rendahnya tingkat pendidikan penduduk di propinsi Jambi, dimana masih lebih dari $55 \%$ penduduk tidak tamat Pendidikan Dasar (SLTP/sederajat) dan hanya 5,36 \% penduduk yang tamat perguruan tinggi (dari D1 sampai dengan S2).

b. Dari tiga infrastruktur (jalan, listrik, telepon) yang diestimasi untuk propinsi Jambi (10 kabupaten/kota), infrastruktur listrik mempunyai elastisitas yang terbesar yaitu 0,591 disusul oleh jalan sebesar 0,499, dan telepon sebesar 0,067.

\section{Saran}

Berdasarkan hasil penelitian mengenai pengaruh pembangunan infrastruktur terhadap pertumbuhan ekonomi di propinsi Jambi dapat disarankan beberapa hal sebagai berikut:

1. Pemerintah Daerah Propinsi Jambi perlu memberi perhatian yang lebih besar terhadap pembangunan infrastruktur terutama infrastruktur yang memberikan pengaruh yang besar terhadap pertumbuhan ekonomi seperti penambahan panjang dan perbaikan jalan, peningkatan kapasitas listrik, penambahan dan peningkatan jangkauan layanan air bersih serta peningkatan dan penambahan kualitas layanan telepon

2. Selain mengejar pertumbuhan, pemerataan pembangunan hendaknya juga diperhatikan oleh pemerintah, karena dalam jangka panjang interkoneksi antar berbagai infrastruktur tersebut secara meluas akan memberikan potensi pertumbuhan yang lebih baik. Hal ini dapat dibuktikan dengan cukup besarnya pengaruh infrastruktur terhadap pertumbuhan ekonomi. 
3. Pembangunan infrastruktur sebaiknya disesuaikan dengan kondisi geografis dan demografis serta kontribusinya terhadap perekonomian.

4. Pelaksanaan otonomi daerah diharapkan dapat memberikan arah yang lebih positif bagi pembangunan infrastruktur secara merata di seluruh daerah di propinsi Jambi. Untuk itu pemerintah propinsi Jambi harus menjalin sinergitas yang lebih baik dengan pemerintah daerah kabupaten/kota dan menyiapkan konsepsi dan peraturan terkait pembangunan infrastruktur.

\section{DAFTAR PUSTAKA}

Amrullah, Taufiq, 2006, Analisis Pengaruh Pembangunan Infrastruktur Terhadap Pertumbuhan Ekonomi Regional di Indonesia, Jakarta FE UI.

BPS, Pendapatan Domestik Regional Bruto Kabupaten/Kota di Indonesia Menurut Lapangan Usaha, $2004-2014$

BPS Propinsi Jambi, 2004-2014, Jambi Dalam Angka Tahun 1996-2009, Jambi

Canning, D. \& P. Pedroni, 1999. Infrastructure and Long Run Economic Growth, Consulting Assistance on Economic Reform II. Discussion Paper no. 57.

Fay, M. 1999. Financing the Future: Infrastruktur Needs in Latin America 2000-2005. The World Bank.

Fox, J. Kevin \& Samara, Zeitch. Juli 2004. Productivity and Public Sector, Prepared for the Productivity: Performance, Prospects \& Policy Workshop.

Infrastruktur, 2004. Prasyarat Pertumbuhan Ekonomi Nasional, Volume 01 Edisi 05. Jakarta.

KKPPI, 2005. Infrastructure Summit, Kementerian Koordinator Bidang Perekonomian, Jakarta.

KKPPI, 2006. Siaran Pers Paket Kebijakan Infrastruktur, Kementerian Koordinator Bidang Perekonomian, Jakarta.

Munnel, A.H. 1992. How Does Public Infrastructure Affect Regional Economy Performance? New England Economic Review.

Setiadi, Elen. 2006, Pengaruh Pembangunan Infrastruktur Dasar Terhadap Pertumbuhan Ekonomi Regional Indonesia (8 Propinsi di Sumatera), Jakarta. FE UI.

Tasman, Aulia, 2008. Ekonomi Produksi, Analisis, Efisiensi dan Produktifitas. Chandra Pratama Cet.I, Jakarta.

Todaro, M.P., Stephen C. Smith, 2006, Pembangunan Ekonomi Jilid I, Edisi kesembilan, Erlangga, Jakarta. 
Weisbrod, Glen \& Frederick Treys. 1998. Productivity \& Accessibility: Bridging Project and Macroeconomics Analisys of Transportation Investments. Journal of Transportatiion and Statistic, Volume I, number 3

Widarjono, Agus, 2007.Ekonometrika Teori dan Aplikasi untuk Ekonomi dan Bisnis, Ekonisia FE UII, Yogyakarta. 